\title{
QUALITY FORMATION OF UNFORTIFIED STRAWBERRY WINE MATERIALS UNDER APPLICATION OF DIFFERENT YEAST RACES
}

\author{
A. Tokar, I. Haidai, O. Yoshyna \\ Uman National University of Horticultere \\ V. Voitsechivskyi \\ National University of Life and Environmental Sciences of Ukraine
}

\begin{tabular}{l}
\multicolumn{1}{c}{ Key words: } \\
Strawberry \\
Cultivar \\
Yeast race \\
Unfortified wine materials \\
\hline \multicolumn{1}{c}{ Article history: } \\
Received 06.11.2018 \\
Received in revised form \\
21.11.2018 \\
Accepted 07.12.2018 \\
\hline
\end{tabular}

Corresponding author:

A. Tokar

E-mail:

npnuht@ukr.net

\begin{abstract}
The article presents the results of a two-year research on the production of unfortified wine materials from strawberries of Polka and Pegas cultivars while using active dry yeasts (ADY), produced in France and Spain.

Two factors influenced significantly the quality formation of wine materials from strawberries: special features of a strawberry cultivar and yeast races. In particular, yeast race (from $52 \%$ to $73 \%$ ) was recorded to have an overwhelming influence on the accumulation of ethanol, total residual sugars, volatile acids and residual extract. And only mass concentration of titrated acids depended mainly on peculiarities of a cultivar. Wine materials from strawberries of Polka and Pegas cultivars are suitable for the production of wine materials with volume proportion of ethanol $14.8-17.2 \%$, which is sufficient for the production of dessert and sweet unfortified fruit wines.

To ferment the mash from Polka cultivar, the best race was ENSIS LE-1, from Pegas cultivar - EC-1118, and from both cultivars - ENSIS LE-6. Simultaneously, in all variants under the application of ENSIS LE-Cl the fermentation was considerably incomplete. According to the mass concentration of volatile acids $\left(0.53-1.12 \mathrm{~g} / \mathrm{dm}^{3}\right)$ the wine materials met requirements, and according to the concentration of residual extract they exceed the norm by 1.3-3.1 times. Mass concentration of titrated acids in wine materials made up 9.2$11.4 \mathrm{~g} / \mathrm{dm}^{3}$, which allows to use them for unblended wine under egalisation or in blendings of unfortified wines.

Therefore, before preparing mashes from the fruit of Polka and Pegas cultivars for fermentation, it is necessary to normalize them according to the mass concentration of titrated acids. Active acidity of wine materials was 3.48-3.67 units $\mathrm{pH}$. Low oxidized wine materials were obtained, reduction-oxidation potential is even, 188-205 $\mathrm{mV}$ with good organoleptic parameters of quality.
\end{abstract}

DOI: $10.24263 / 2225-2924-2018-24-6-23$ 


\title{
ФОРМУВАННЯ ЯКОСТІ НЕКРІПЛЕНИХ СУНИЧНИХ ВИНОМАТЕРІАЛІВ ЗА ВИКОРИСТАННЯ РІЗНИХ РАС ДРІЖДЖІВ
}

\author{
А.Ю. Токар, І.В. Гайдай, О.Ю. Юшина \\ Уманський начіональний університет садівнищтва \\ В.І. Войцехівський \\ Національний університет біоресурсів і природокористування України
}

У статті наведено результати дворічних досліджень виготовлення некріплених виноматеріалів з ягід суниці садової сортів Полка і Пегас за застосування активних сухих дріжджів (АСД) виробництва Франиії та Іспанії.

3'ясовано, що на формування якості виноматеріалів з ягід суниці істотно впливали два фактори: особливості сорту і раса дріжджів. Зокрема, відмічався переважаючий вплив раси дріжджів (від 52 до 73\%) на накопичення етилового спирту, масову концентрацію залишкових иукрів, летких кислот $i$ залишкового екстракту. I лише масова концентрація титрованих кислот залежала переважно від особливостей сорту. Виноматеріали з ягід суничі садової сортів Полка і Пегас придатні для виготовлення виноматеріалів 3 об 'смною часткою етилового спирту 14,8-17,2\%, що достатньо для виробництвв десертних чи солодких некріплених плодово-ягідних вин.

Для збродження сусел з сорту Полка кращою була раса ENSIS LE-1, з сорту Пегас - EC-1118, з обох сортів - ENSIS LE-6. Одночасно за застосування раси дріжджів ENSIS LE-C1 у всіх варіантах отримано значні «недоброди». За масовою концентрацією летких кислот $\left(0,53-1,12\right.$ г/дм $\left.{ }^{3}\right)$ виноматеріали відповідали чинним вимогам, а за масовою концентрачією залишкового екстракту переважали норму в 1,3-3,1 раза. Масова конщентрація ти-

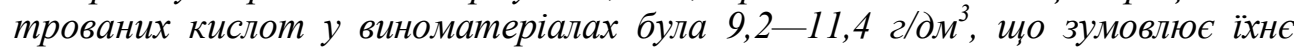
використання для сортових вин за егалізації чи в купажах некріплених вин.

Тому в майбутньому перед закладанням сусел із ягід сунищі сорту Полка $i$ Пегас на бродіння необхідно нормалізувати їх за масовою конщентрацією титрованих кислот. Активна кислотність виноматеріалів - 3,48-3,67 од. pH. Отримано мало окиснені виноматеріали $($ ОВП-188-205 мB) з відповідними органолептичними показниками якості.

Ключові слова: сунияя садова, сорт, раса дріжджів, некріплені виноматеріали.

Постановка проблеми. У всьому світі держави підтримують створення малих фермерських господарств, які стимулюють розвиток садівництва, виноградарства і бджільництва [1]. Закон України «Про внесення змін до деяких законодавчих актів України щодо розвитку теруарних вин і натуральних медових напоїв» 32018 р. затверджує правовий статус малих виробників виноробної продукції та суттєво спрощує процедуру ліцензування, а також вихід на ринок. Більшість дрібних фермерів орієнтовані на вирощування плодовоягідної сировини, а не продукту для свіжого ринку. Тому прибуток у них 
незначний і зростає потреба у створенні доданої вартості. Ще у 90 -х роках минулого століття плодово-ягідне вино було наявне у магазинах, але його масове виробництво припинилось через несприятливі зміни у законодавстві [2].

Аналіз останніх досліджень і публікацій. В останні роки на ринку виноробної продукції займають помітне місце та $є$ цікавими для споживача вина 3 ароматних ягід та плодів, зокрема із суниці, чорної смородини, малини, вишні [3]. В.В. Скрипником розроблено теоретичні основи виготовлення фруктанів (за чинним ДСТУ некріплених плодово-ягідних вин), що значно переважають за якістю кріплені вина та мають набагато складнішу технологію. Процес бродіння тривалий, потребує контролю та регулювання [4]. На думку сучасних виноробів, важливо зберегти якість сировини наскільки це можливо. Хоч втрати $є$ неминучими, але чим менші, тим кращий результат. I другий секрет - не роби занадто багато, спостерігай, контролюй [5]. У виробництві плодово-ягідних вин важливе значення має обов'язкове пастеризування сусел до внесення культурних дріжджів. Механізм взаємодії селекціонованих дріжджів 3 дикою мікрофлорою вивчено недостатньо, але за співвідношення 1:20 можна сподіватись на позитивний результат [6]. Дріжджі Saccharomyces $є$ основними агентами спиртового бродіння і відіграють головну роль у технології виноробства. Важливими характеристиками рас $\epsilon$ збродження різних цукрів, інтенсивність дихання і бродіння, асиміляція нітратів, використання етанолу, формування продуктів метаболізму тощо [7]. Селекціонуються нові штами винних дріжджів, що виділяються короткою лагфазою, високою ферментативною активністю без будь-якого сповільнення чи ризику зупинення бродіння, мінімальним продукуванням $\mathrm{SO}_{2}$ i $\mathrm{H}_{2} \mathrm{~S}$ [8]. Окремі характеризуються підвищеною стійкістю до високої температури [9] та органічних кислот [10].

Мета дослідження: оцінити придатність ягід суниці садової сортів Полка і Пегас для виготовлення некріплених виноматеріалів за використання активних сухих дріжджів. Для цього поставлено такі завдання: дослідити якість некріплених виноматеріалів за фізико-хімічними, непрямими й органолептичними показниками залежно від сорту і раси дріжджів; визначити придатність виноматеріалів для виготовлення солодких і десертних плодово-ягідних некріплених вин;виділити кращі раси дріжджів, які можна застосовувати у виробництві суничних виноматеріалів.

Викладення основних результатів дослідження. Дослідження виконували в Уманському національному університеті садівництва на кафедрі технології зберігання і переробки плодів та овочів у 2016-2018 роках. Для досліджень брали ягоди суниці сортів Полка та Пегас, з яких одержували соки та готували сусла, початкова цукристість яких була достатньою для отримання некріплених виноматеріалів за об'ємною часткою етилового спирту (15,3-17,2\%), придатних для виготовлення солодкого та десертного суничного вина. Сусла пастеризували за температури $80-85^{\circ} \mathrm{C}$ протягом 5 хвилин, охолоджували, розливали у стерильну тару й додавали активні сухі дріжджі: EC-1118 роду Saccharomyces bayanus (Франція, контроль), Saccharomyces cerevisiae ENSIS LE-C1, ENSIS LE-1, ENSIS LE-5, ENSIS LE-6 (Іспанія) відповідно до рекомендацій виробників (20 г на 100 л сусла). Температура 
бродіння сусел $-20-25^{\circ} \mathrm{C}$. Під час бродіння контролювали зміну маси сусла. Після закінчення бродіння, ущільнення осаду й освітлення виноматеріалу, останній відділяли від осаду й визначали: об'ємну частку етилового спирту ареометричним методом; масову концентрацію залишкових цукрів - прямим титруванням; титрованих кислот (в перерахунку на яблучну кислоту) титриметричним методом; летких кислот — методом ступеневої відгонки; залишковий екстракт - як різницю між загальним екстрактом і масовими концентраціями цукрів і титрованих кислот; активну кислотність і окисновідновний потенціал (ОВП) - В.Г. Гержикова [11]. Органолептичну оцінку проводили на засіданні дегустаційної комісії. Хіміко-технологічну оцінку рас дріжджів - за методикою А.Ю. Токар, В.І. Войцехівський [12].

Дослідження виконували у трьох повтореннях. Статистичну обробку отриманих результатів обробляли методом дисперсійного аналізу з використанням спеціальних пакетів програм.

Процес бродіння суничних сусел у 2016 р. тривав 77 діб у більшості варіантів, а з расами дріжджів ENSIS LE-1 3 обох сортів та ENSIS LE-6 із сорту Пегас - 70 діб. У результаті сформувались виноматеріали 3 фізико-хімічними показниками якості, що наведені у табл. 1.

За вмістом етилового спирту виноматеріали з ягід сорту Полка, що отримані з расами дріжджів ENSIS LE-1 і ENSIS LE-6, та з ягід сорту Пегас, що отримані з расами дріжджів EC-1118 і ENSIS LE-6, можуть бути використані для виготовлення десертного суничного вина.

Проте окремі виноматеріали, в яких об'ємна частка етилового спирту рівна чи більша $14,8 \%$, придатні для виготовлення некріплених солодких вин відповідно до чинного в Україні стандарту на плодово-ягідні вина. Ті виноматеріали, що мали нижчий показник, придатні для купажування чи виготовлення вин покращеної якості.

Результати дисперсійного аналізу вказали на переважаючий вплив раси дріжджів (66\%) на накопичення етилового спирту й вміст залишкових цукрів у виноматеріалах. Масова концентрація інших показників також більшою мірою залежала від застосованої раси дріжджів, за винятком титрованих кислот, вміст яких залежав значно від особливостей сорту суниці.

Усі виноматеріали мали підвищену масову концентрацію титрованих кислот, оскільки для сортових десертних вин їхній вміст у виноматеріалах не повинен перевищити 9,1 г/дм $^{3}$, а для солодких $-8,7$ г/дм $^{3}$. Тобто за цим показником виноматеріали придатні для купажних некріплених вин.

Таблиця 1. Фізико-хімічні показники якості суничних виноматеріалів урожаю 2016 року

\begin{tabular}{|c|c|c|c|c|c|c|}
\hline \multirow[b]{2}{*}{ Сорт } & \multirow[b]{2}{*}{ Раса дріжджів } & \multirow[b]{2}{*}{$\begin{array}{c}\text { Об’ємна частка } \\
\text { етилового } \\
\text { спирту, \% }\end{array}$} & \multicolumn{4}{|c|}{ Масова концентрація, г/дм } \\
\hline & & & $\begin{array}{c}\text { залиш- } \\
\text { кових } \\
\text { цукрів }\end{array}$ & $\begin{array}{c}\text { титрованих } \\
\text { кислот } \\
\text { (втрати,_\%) }\end{array}$ & $\begin{array}{l}\text { летких } \\
\text { кислот }\end{array}$ & $\begin{array}{c}\text { залишкового } \\
\text { екстракту }\end{array}$ \\
\hline 1 & 2 & 3 & 4 & 5 & 6 & 7 \\
\hline Полка & $\begin{array}{c}\text { EC-1118 } \\
\text { (контроль) }\end{array}$ & 15,0 & 8,2 & $10,0(6,5)$ & 0,79 & 17,3 \\
\hline
\end{tabular}


Продовження табл. 1

\begin{tabular}{|c|c|c|c|c|c|c|}
\hline 1 & 2 & 3 & 4 & 5 & 6 & 7 \\
\hline \multirow{4}{*}{ Полка } & ENSIS LE-C1 & 10,5 & 84,8 & $10,3(3,7)$ & 1,05 & 9,3 \\
\cline { 2 - 7 } & ENSIS LE-1 & 15,3 & 3,0 & $10,7(0,0)$ & 0,72 & 17,4 \\
\cline { 2 - 7 } & ENSIS LE-5 & 14,7 & 13,0 & $10,1(5,6)$ & 0,79 & 14,5 \\
\cline { 2 - 7 } & ENSIS LE-6 & 15,4 & 2,0 & $9,7(9,3)$ & 0,66 & 18,2 \\
\hline \multirow{5}{*}{ Пегас } & $\begin{array}{c}\text { EC-1118 } \\
\text { (контроль) }\end{array}$ & 15,4 & 0,0 & $10,1(1,0)$ & 0,92 & 16,2 \\
\cline { 2 - 7 } & ENSIS LE-C1 & 11,6 & 66,1 & $9,7(5,0)$ & 1,12 & 11,4 \\
\cline { 2 - 7 } & ENSIS LE-1 & 13,8 & 28,7 & $9,2(8,8)$ & 0,99 & 13,2 \\
\cline { 2 - 7 } & ENSIS LE-5 & 13,5 & 34,0 & $9,3(8,8)$ & 0,86 & 15,8 \\
\cline { 2 - 7 } & ENSIS- E-6 & 15,3 & 3,0 & $9,6(5,9)$ & 0,86 & 25,0 \\
\hline \multicolumn{2}{|c|}{} & 0,2 & 1,1 & 0,2 & 0,03 & 0,3 \\
\hline
\end{tabular}

За масовою концентрацією летких кислот виноматеріали відповідали чинним вимогам (не більше 1,3 г/дм ${ }^{3}$.

Залишковий екстракт у більшості варіантів був вищим від 12 г/дм³, на цей показник крім раси дріжджів (46\%), впливали особливості сорту (17) та взаємодія факторів (46\%). Негативний вплив раси дріжджів на показник виявився у виноматеріалах з ягід сорту Полка та Пегас у варіанті з расою ENSIS LE-C1, де залишковий екстракт був нижче за норму.

За результати хіміко-технологічної оцінки рас дріжджів (табл. 2) можна зробити висновок, що для зброджування сусел з ягід сорту Полка кращою буде раса дріжджів ENSIS LE-1 i ENSIS LE-6. Для зброджування високо цукристих сусел з ягід сорту Пегас - раси EC-1118 та ENSIS-LE-6.

Таблиия 2. Хіміко-технологічна оцінка рас дріжджів за виноматеріалами з ягід суниці урожаю 2016 року

\begin{tabular}{|c|c|c|c|c|c|c|c|c|}
\hline \multirow[b]{2}{*}{$\begin{array}{l}\text { Сорт } \\
\text { суниці }\end{array}$} & \multirow[b]{2}{*}{ Раса дріжджів } & \multirow[b]{2}{*}{ 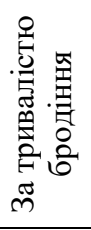 } & \multicolumn{5}{|c|}{ Оцінка за вмістом: } & \multirow[b]{2}{*}{$\begin{array}{c}\text { Зага- } \\
\text { льна } \\
\text { оцінка }\end{array}$} \\
\hline & & & 空 & 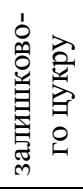 & 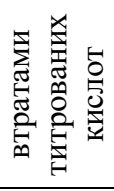 & 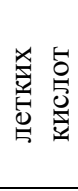 & 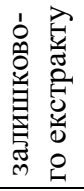 & \\
\hline \multirow{5}{*}{ Полка } & $\begin{array}{c}\text { EC-1118 } \\
\text { (контроль) }\end{array}$ & 0,91 & 0,8 & 0,74 & 0,75 & 0,87 & 0,91 & 4,98 \\
\hline & ENSIS LE-C1 & 0,91 & 0,00 & 0,00 & 1,0 & 0,39 & 0,11 & 2,41 \\
\hline & ENSIS LE-1 & 1,00 & 0,95 & 1,00 & 1,00 & 0,94 & 0,92 & 5,81 \\
\hline & ENSIS LE-5 & 0,91 & 0,65 & 0,50 & 0,84 & 0,87 & 0,63 & 4,40 \\
\hline & ENSIS LE-6 & 0,91 & 1,00 & 1,00 & 0,47 & 1,00 & 1,00 & 5,38 \\
\hline \multirow{5}{*}{ Пегас } & $\begin{array}{c}\mathrm{EC}-1118 \\
\text { (контроль) }\end{array}$ & 0,91 & 1,00 & 1,00 & 1,00 & 0,94 & 0,12 & 4,97 \\
\hline & ENSIS LE-C1 & 0,91 & 0,00 & 0,00 & 0,90 & 0,54 & 0,00 & 2,35 \\
\hline & ENSIS LE-1 & 1,00 & 0,20 & 0,00 & 0,42 & 0,87 & 0,00 & 2,49 \\
\hline & ENSIS LE-5 & 0,91 & 0,05 & 0,00 & 0,52 & 1,0 & 0,08 & 2,56 \\
\hline & ENSIS LE-6 & 1,00 & 0,95 & 1,00 & 0,81 & 1,00 & 1,00 & 5,76 \\
\hline
\end{tabular}

Бродіння суничних сусел у 2017 р. тривало 91 добу. Фізико-хімічні показники якості виноматеріалів наведено у табл. 3 . 
Результати дисперсійного аналізу показують переважаючий вплив на формування якості виноматеріалів застосованої раси дріжджів. Сила впливу складала від 52 до 73\% на всі фізико-хімічні показники виноматеріалів і лише на масову концентрацію титрованих кислот вагоміше впливали особливості сорту (сила впливу 55\%).

Таблиия 3. Фізико-хімічні показники якості суничних виноматеріалів урожаю 2017 року

\begin{tabular}{|c|c|c|c|c|c|c|}
\hline \multirow[b]{2}{*}{ Сорт } & \multirow[b]{2}{*}{ Раса дріжджів } & \multirow{2}{*}{$\begin{array}{c}\text { Об’ємна } \\
\text { частка } \\
\text { етилового } \\
\text { спирту, \% } \\
\end{array}$} & \multicolumn{4}{|c|}{ Масова концентрація, г/дм ${ }^{3}$} \\
\hline & & & $\begin{array}{c}\text { залиш- } \\
\text { кових } \\
\text { цукрів }\end{array}$ & $\begin{array}{c}\text { титрованих } \\
\text { кислот } \\
\text { (втрати, \%) }\end{array}$ & $\begin{array}{l}\text { летких } \\
\text { кислот }\end{array}$ & $\begin{array}{c}\text { залиш- } \\
\text { кового } \\
\text { екстракту }\end{array}$ \\
\hline \multirow{5}{*}{ Полка } & $\begin{array}{c}\text { EC-1118 } \\
\text { (контроль) }\end{array}$ & 15,0 & 37,0 & $10,0(9,0)$ & 0,83 & 25,8 \\
\hline & ENSIS LE-C1 & 14,8 & 41,0 & $10,7(2,7)$ & 0,70 & 34,7 \\
\hline & ENSIS LE-1 & 17,0 & 3,0 & $10,7(2,7)$ & 0,73 & 36,6 \\
\hline & ENSIS LE-5 & 17,2 & 0,0 & $10,4(5,5)$ & 0,86 & 29,1 \\
\hline & ENSIS LE-6 & 17,4 & 0,0 & $10,7(2,7)$ & 0,83 & 31,0 \\
\hline \multirow{5}{*}{ Пегас } & $\begin{array}{c}\text { EC-1118 } \\
\text { (контроль) }\end{array}$ & 16,0 & 3,0 & $11,2(2,6)$ & 0,90 & 27,8 \\
\hline & ENSIS LE-C1 & 14,3 & 31,0 & $11,0(4,5)$ & 0,63 & 15,2 \\
\hline & ENSIS LE-1 & 15,2 & 17,0 & $10,7(7,0)$ & 0,53 & 30,2 \\
\hline & ENSIS LE-5 & 15,8 & 7,0 & $11,2(2,6)$ & 0,80 & 24,3 \\
\hline & ENSIS LE-6 & 15,4 & 14,0 & $11,4(0,9)$ & 0,76 & 25,1 \\
\hline & $\mathrm{HIP}_{05}$ & 0,2 & 1,0 & 0,2 & 0,03 & 0,5 \\
\hline
\end{tabular}

У суничних виноматеріалах 3 ягід урожаю 2017 р. накопичилося значно більше етилового спирту і більшість 3 них були придатні для виготовлення десертних вин. Виняток складали виноматеріали з ягід суниці сорту Полка, сформовані за участі рас дріжджів EC-1118 і ENSIS LE - C1, та з сорту Пегас ENSIS LE-C1 i ENSIS LE-1. Проте об'ємна частка етилового спирту в них достатня для приготування солодких некріплених вин. У зазначених варіантах підвищена масова концентрація залишкових цукрів, отримано «недоброди». Лише у варіантах з ягід сорту Полка раси дріжджів ENSIS LE-5 і ENSIS-LE-6 повністю утилізували цукри сусел.

Вміст титрованих кислот у виноматеріалах з ягід обох сортів підвищений, що може бути виправлено егалізацією чи купажуванням. Летких кислот у виноматеріалах 3 ягід урожаю 2017 р. утворилося менше порівняно 3 аналогічними $з$ ягід урожаю 2016 р. (див. табл. 1, 2).

Виноматеріали з ягід урожаю 2017 р. вигідно відрізнялися за масовою концентрацією залишкового екстракту, що перевищував допустиму норму в 1,3-3,1 раза. Дещо вищим вмістом характеризувалися виноматеріали з ягід сорту Полка порівняно з аналогічними з сорту Пегас. Можна припустити, що це пов'язано з вищим накопиченням додаткових продуктів бродіння.

Кращими були варіанти з суниці сорту Полка, зброджені расами дріжджів ENSIS LE-1 та ENSIS-LE-6, які переважали расу EC-1118, взяту за контроль. У виноматеріалах із сорту Пегас — 3 расою ЕС-1118 (табл. 4). 
За показниками двох років (табл. 2, 4) можна рекомендувати для зброджування високоцукристих сусел з ягід суниці садової сорту Полка раси дріжджів ENSIS LE-1 i ENSIS LE-6, із сорту Пегас - EC-1118 і ENSIS LE-6.

Таблиця 4. Хіміко-технологічна оцінка рас дріжджів за виноматеріалами $з$ ягід суниці врожаю 2017 року

\begin{tabular}{|c|c|c|c|c|c|c|c|c|}
\hline \multirow[b]{2}{*}{$\begin{array}{l}\text { Сорт } \\
\text { суниці }\end{array}$} & \multirow[b]{2}{*}{ Раса дріжджів } & \multirow[b]{2}{*}{ 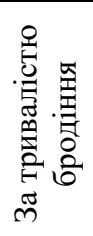 } & \multicolumn{5}{|c|}{ Оцінка за вмістом } & \multirow[b]{2}{*}{$\begin{array}{c}\text { Зага- } \\
\text { льна } \\
\text { оцінка }\end{array}$} \\
\hline & & & $\begin{array}{l}\overrightarrow{0} \\
\text { : } \\
\text { : }\end{array}$ & 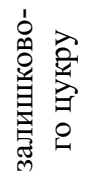 & 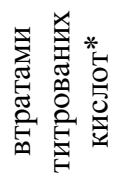 & 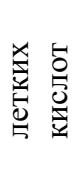 & 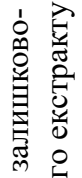 & \\
\hline \multirow{5}{*}{ Полка } & $\begin{array}{c}\text { EC-1118 } \\
\text { (контроль) }\end{array}$ & 1,00 & 0,00 & 0,00 & 0,49 & 0,87 & 0,00 & 2,36 \\
\hline & ENSIS LE-C1 & 1,00 & 0,00 & 0,00 & 1,00 & 1,00 & 0,81 & 3,81 \\
\hline & ENSIS LE-1 & 1,00 & 0,80 & 1,00 & 1,00 & 0,97 & 1,00 & 5,77 \\
\hline & ENSIS LE-5 & 1,00 & 0,90 & 1,00 & 0,85 & 0,84 & 0,25 & 4,84 \\
\hline & ENSIS LE-6 & 1,00 & 1,00 & 1,00 & 1,00 & 0,87 & 0,44 & 5,31 \\
\hline \multirow{5}{*}{ Пегас } & $\begin{array}{c}\text { EC-1118 } \\
\text { (контроль) }\end{array}$ & 1,00 & 1,00 & 1,00 & 1,00 & 0,63 & 0,76 & 5,39 \\
\hline & ENSIS LE-C1 & 1,00 & 0,15 & 0,00 & 0,95 & 0,97 & 0,00 & 3,02 \\
\hline & ENSIS LE-1 & 1,00 & 0,60 & 0,30 & 0,70 & 1,00 & 1,00 & 4,60 \\
\hline & ENSIS LE-5 & 1,00 & 0,90 & 0,80 & 1,00 & 0,73 & 0,41 & 4,84 \\
\hline & ENSIS LE-6 & 1,00 & 0,70 & 0,45 & 1,00 & 0,77 & 0,49 & 4,41 \\
\hline
\end{tabular}

Активна кислотність (табл. 5) впливає на смак, характеризує мікробіологічну стабільність харчових продуктів, визначається складом органічних кислот $\mathrm{i}$ ступенем їх дисоціації.

Важливим показником для виноматеріалів $є$ окисно-відновний потенціал (табл. 5). Він характеризує ступінь їх окиснення. Чим нижчий цей показник, тим вища якість. 3 метою зниження ОВП у сусло можна вводити діоксид сірки або проводити теплове пастеризування виноматеріалів, за рахунок цього окисно-відновний потенціал може знижуватись на 6-11 мВ.

Таблиця 5. Активна кислотність та окисно-відновний потенціал некріплених виноматеріалів 3 ягід суниці

\begin{tabular}{|c|c|c|c|c|c|}
\hline \multirow{2}{*}{$\begin{array}{c}\text { Сорт } \\
\text { суниці }\end{array}$} & \multirow{2}{*}{ Раса дріжджів } & \multicolumn{4}{|c|}{ Рік урожаю } \\
\cline { 3 - 6 } & & \multicolumn{2}{|c|}{2016} & \multicolumn{2}{c|}{2017} \\
\hline 1 & 2 & 3 & 4 & 5 & 6 \\
\hline \multirow{5}{*}{ Полкивна кислот- } & ОВП, мB & $\begin{array}{c}\text { Активна кислот- } \\
\text { ність, од. } \mathrm{pH}\end{array}$ & ОВП, мВ \\
\hline & $\begin{array}{c}\text { ЕС-1118 } \\
\text { (контроль) }\end{array}$ & 3,54 & 199 & 3,62 & 193 \\
\cline { 2 - 6 } & ENSIS LE-C1 & 3,64 & 197 & 3,61 & 193 \\
\cline { 2 - 6 } & ENSIS LE-1 & 3,52 & 199 & 3,64 & 191 \\
\cline { 2 - 6 } & ENSIS LE-5 & 3,56 & 198 & 3,64 & 192 \\
\cline { 2 - 6 } & ENSIS LE-6 & 3,57 & 198 & 3,64 & 192 \\
\hline
\end{tabular}




\begin{tabular}{|c|c|c|c|c|c|}
\hline \multicolumn{3}{|c}{} \\
\hline 1 & 2 & 3 & 4 & 5 & \multicolumn{2}{c|}{ Продовження табл. 5 } \\
\hline \multirow{4}{*}{ Пегас } & $\begin{array}{c}\text { EC-1118 } \\
\text { (контроль) }\end{array}$ & 3,51 & 202 & 3,70 & 188 \\
\cline { 2 - 6 } & ENSIS LE-C1 & 3,48 & 205 & 3,65 & 191 \\
\cline { 2 - 6 } & ENSIS LE-1 & 3,51 & 203 & 3,67 & 189 \\
\cline { 2 - 6 } & ENSIS LE-5 & 3,57 & 200 & 3,67 & 189 \\
\cline { 2 - 6 } & ENSIS LE-6 $^{2}$ & 3,48 & 204 & 3,66 & 191 \\
\hline & HIP $_{05}$ & 0,03 & 2,4 & 0,03 & 2,1 \\
\hline
\end{tabular}

Заключний висновок про доброякісність виноматеріалів та вин дається на підставі органолептичного дослідження. Результати дегустаційної оцінки некріплених виноматеріалів з ягід суниці наведено в табл. 6.

За інструкцією з визначення якості радянського шампанського, коньяків, виноматеріалів, виноградних і плодово-ягідних гранично допустима норма оцінки нових виноматеріалів повинна бути не нижче 7 балів.

Беручи це до уваги, можна зробити висновок, що всі представлені зразки некріплених суничних виноматеріалів виявились придатними до впровадження у виробництво, крім виноматеріалу, виготовленого із сорту суниці Полка у 2016 р. і збродженого расою дріжджів ENSIS LE-C1 (табл. 6).

Таблиия 6. Дегустаційна оцінка некріплених суничних виноматеріалів, бал

\begin{tabular}{|c|c|c|c|c|}
\hline \multirow{2}{*}{ Раса дріжджів } & \multicolumn{5}{|c|}{ Роки досліджень } \\
\cline { 2 - 5 } & \multicolumn{3}{|c|}{2016} & \multicolumn{2}{c|}{2017} \\
\cline { 2 - 5 } & \multicolumn{4}{|c|}{ Сорти суниці } \\
\cline { 2 - 5 } & Полка & Пегас & Полка & Пегас \\
\hline EC-1118 (контроль) & 7,95 & 8,30 & 8,40 & 8,77 \\
\hline ENSIS LE-C1 & 6,65 & 8,14 & 7,99 & 8,60 \\
\hline ENSIS LE-1 & 7,56 & 7,37 & 7,03 & 7,79 \\
\hline ENSIS LE-5 & 7,34 & 7,73 & 7,76 & 8,17 \\
\hline ENSIS LE-6 $^{*} 7,76$ & 7,38 & 8,20 & 7,80 \\
\hline HIP $_{05}$ & \multicolumn{3}{|c|}{0,06} & \multicolumn{3}{c|}{0,09} \\
\hline
\end{tabular}

\section{Висновки}

1. Ягоди суниці садової сортів Полка та Пегас придатні для виготовлення некріплених виноматеріалів. Через підвищену масову концентрацію титрованих кислот у досліджуваних виноматеріалах вони можуть бути використані для десертних чи солодких вин після егалізації чи для використання у купажах. Тому в майбутньому необхідно нормалізувати суничні сусла до бродіння за масовою концентрацією титрованих кислот: не вище 8,7 г/дм ${ }^{3}-$ для солодких та не вище 9,1 г/дм ${ }^{3}$ - для десертних вин.

2. Відповідні результати при формуванні якості виноматеріалів з ягід суниці садової сорту Полка забезпечують раси дріжджів ENSIS LE-1, ENSIS LE-6, з сорту Пегас - paca EC-1118, ENSIS LE-6. Зазначені раси можуть бути рекомендовані для застосування у виробництві суничних некріплених виноматеріалів. 


\section{Лiтература}

1. Луканин А.С. Украинское вино с импортным привкусом или что мешает производству качественного отечественного продукта. Напитки. Инновации и Технологии. 2014. № $1-2$. C. $26-29$.

2. Литовченко О.М. Про перспективи відновлення виноробної галузі України у сегменті малого виробництва виноградних та плодово-ягідних вин, медових напоїв та сидрів. URL: docs.infoindustria.com.ua/sdocs/agroindustry. Агроиндустрия [cateqories] Infoindustria sDocs.

3. Панасюк А.Л., Кузьмина Е.И., Егорова О.С. Трансформация сахаров и органических кислот в ягодных соках и производстве напитков и вин. Напитки. Технологии и Инновациии. 2014. Январь-февраль. С. 75-77.

4. Скрыпник В.В. Фруктаны. Киев: Изд-во УСХА, 1992. 99 с.

5. Долл Т. Главный «секрет» настоящего винодела - наблюдать, контролировать и не делать больше ничего чем не обходимо. Технологии. Инновации. 2015. № 9. С. 22-24.

6. Взаимодействие микроорганизмов в виноделии: теоретические и практические аспекты. Напитки. Технологии и Инновации. 2014. № 5(34). С. 31-34.

7. Смірнова Ю.В., Голодок Л.П., Вінніков А.І. Біологічні особливості винних дріжджів роду Saccharomyces, що використовуються у виробництві виноматеріалів // Хімія та сучасні технології: тези доповідей Ү Міжнародної наук.-техн. конференції студентів, аспірантів та молодих вчених (Дніпропетровськ, 20-22 квітня 2011 р.).Дніпропетровськ, 2011. C. 505.

8. Селекция нового штамма винных дрожжей с высокой ферментативной активностью при минимальном синтезе $\mathrm{SO}_{2}, \mathrm{H}_{2} \mathrm{~S}$ и ацетальдегидов / Пер. И Монастерецкой. Технологии. Инновации. 2015. № 4. С. 24-26.

9. Gourraud C., Marullo P., Mansour C., and Dobourdieu D. (2009) Using directed breeding to improve yeast strains, The Australian Grape grower and Winemaker, January Issue, P. $63-68$.

10. Boulton R.B., Singleton V.L., Bisson L.F. and Kunkee R.E. Principles and practices of winemaking, Aspen: Gaithersberg, Maryland, 1999. P. 172.

11. Гержикова В. Г. Методи техніко-хімічного контролю у виноробстві. Сімферополь: Таврида, 2009. 304 с.

12. Токар А.Ю., Войцехівський В.І. Методика визначення кращої раси дріжджів при виготовленні некріплених плодово-ягідних вин. Наук. вісн. Наџ. аграрного ун-ту. Київ, 2008. Вип. 118. С. $245-250$. 